\title{
RANGE OF COSMETICS BASED ON NATURAL EXTRACTS WITH ROLE OF PROTECTION AGAINST ENVIRONMENTAL POLLUTION FACTORS
}

\author{
Stefan Manea ${ }^{1}$, Viorica Tamas ${ }^{1}$, Viorica Carabela ${ }^{1}$, Andreea Dima $^{1}$, Cristina Luntraru ${ }^{1}$ \\ 1S.C. HOFIGAL Export-Import S.A., No. 2 Intrarea Serelor Street, zip code 042124, District 4, \\ Bucharest, Romania, cercetare@hofigal.eu
}

\begin{abstract}
As reaction to risks brought by pollutants, particular attention is given to the development of natural cosmetics with protective role. These new products are created based on innovative active ingredients obtained through advanced processing of native plant species that work by cleaning and removal of polluting impurities and making a protective shield that also stimulates the natural defense mechanisms of skin. The work focuses on harnessing the medicinal plant 'Passion Flower' (Passiflora incarnate), cultivated in ecological conditions for obtaining a liquid extract enriched in active phytochemicals with anti-stress, restorative, invigorating, soothing and purifying properties, for special care of devitalized skin, stress and pollutants abused, or marked by time. The authors have associated the extract of Passionflower with active plant ingredients from fatty oils of milk thistle, hemp, rosehip and sea buckthorn, with concentrated extracts of marshmallow, black currant and licorice and essential lavender oil, to realise an active complex, rich in phytochemical compounds: polyphenols, flavones, flavonoids, anthocyanins, procyanidins, polyunsaturated fatty acids, triterpene saponins, carotenoids and minerals that synergistically act for mutual reinforcing. HOFIGAL Company has created new performing cosmetic formulas with roles of: cleaning and removing of pollutant impurities (cleansing products, shower gels) skin protection by strengthening its 'natural barrier' and natural defense mechanisms (creams, toning emulsions), anti- stress, (creams, gels), maintenance of skin hydration, nutrition and cellular regeneration (lotions, creams). Thereby, five product formulations were developed and efficacy evaluated: Cleansing milk, Cleansing oil for eye contour, Body cream, Protective and hydrating day cream, AntiStress shampoo.
\end{abstract}

Keywords: flavones, hemp, hydration, Passiflora, skin

\section{Introduction}

Fatigue, stress, external aggression and waning cellular regeneration ability profoundly affects the dermal tissue which dehydrates faster, loses tone, elasticity and freshness, favoring the appearance of wrinkles and flabby skin. As reaction to risks brought by pollutants, particular attention is given to the development of natural and organic 'antipollution' cosmetics for hair and skin. These new products are created based on innovative active ingredients obtained through advanced processing of native plant species that work by cleaning and removal of pollutant impurities and making a protective shield that stimulates the natural defense mechanisms of skin.

The work focuses on harnessing the medicinal plant 'Passion Flower' (Passiflora Incarnata), cultivated in ecological conditions for obtaining a liquid extract enriched in active phytochemicals with anti-stress, restorative, invigorating, soothing and purifying properties, for special care of devitalized skin, stress and pollutants abused, or marked by time. The extract of Passion flower was also associated with active ingredients from indigenous medicinal plants, like fatty oils of milk thistle, hemp, rose hip and sea 
buckthorn, with concentrated extracts of marshmallow, black currant and licorice and different essential oils, to realise an active complex, rich in phytochemical compounds: polyphenols, flavonoids, anthocyanins, procyanidins, polyunsaturated fatty acids, triterpene saponins, carotenoids, minerals, etc. that synergistically act for mutual reinforcing. [1].

On this basis, new performant formulas of cosmetic products were developed, with roles of:

- $\quad$ Cleaning and removing pollutant impurities (emusions, oils, shower gels, shampoo)

- $\quad$ skin protection by strengthening the 'natural barrier' and the natural defense mechanisms (creams, tonic emulsions) by combating the effects of stress, early wrinkling and dull looking skin / dark circles, eye bags (creams and gels)

- maintenance of skin hydration, nutrition, cell regeneration (lotions, shower gels, emulsions, creams).

\section{Materials and Methods}

For the development of the presented cosmetic products, several natural materials were used:

- Vegetable fatty oils of: rose hip, safflower, milk thistle, hemp and sea buckthorn, analysed by gas chromatography for the determination of fatty acids

Fatty oils were obtained by 'cold pressing' batch process, technology used to protect the active ingredients against degradation. [2,3]

- $\quad$ Concentrated extracts of marshmallow, black currant and licorice, for which the principal active compounds were identified by specific methods.

Passiflora plant was studied to obtain a concentrated extract suitable for the targeted formulations. Thus, the authors have developed a concentrated extract and a tincture of Passiflora which were spectrophotometrically analysed for the determination of total flavones expressed in vitexin, of polyphenol content and antioxidant activity. [4]

Passiflora liquid extract preparation was performed by Squibb leaching method using chopped plant material from aerial parts of the plant and the appropriate solvent. The technology related to the used method was focused on the realization of an extract obtained by maceration for 10 days at $25^{\circ} \mathrm{C}$. Filtration gave a clear, brown liquid extract, with the characteristic odour;

Tincture of passionflower, on the other hand, was obtained by cold soaking of plant material in alcohol (50 v. \%), for 7 days.

\section{Results and Discussion}

The obtained Passifora liquid extract was characterized by the determination of flavones expressed in vitexin, $0.23 \%$ respectively, the result being compared to values obtained for the plant as such and to the tincture. According to Fig. 1, one can observe the higher content for the extract compared to the tincture, which makes it suitable for use in the intended purpose. The determinations of total polyphenols (as gallic acid) and antioxidant activity (expressed in equiv. TROLOX) gave the following results for passion flower extract:

- $\quad$ Total polyphenols: 0.16 wt. \% galic acid

- $\quad$ Antioxidant activity: 1,79 mols \% TROLOX 


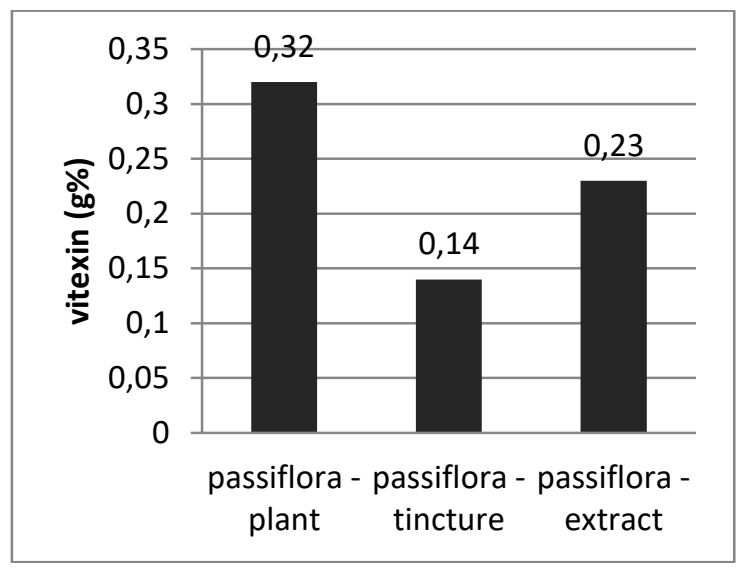

Fig. 10. Flavonoid content expressed in vitexin

Flavonoids present in the extract of Passiflora have antioxidant, antimicrobial, repellent and photoprotective effects. It has the ability to inhibit free radical formation and the role of scavenger for free radicals, sparing vitamin $E$ in cell membranes and low-density proteins, as well as of conservation of polyunsaturated fatty acids in erythrocyte membrane. [5]

Vegetable fatty oils of rose hip, buckthorn, hemp, thistle and safflower plants grown in ecological conditions were selected and analyzed for composition in essential fatty acids (oleic acid, alpha-linolenic, linoleic, and others) These oils fulfilling a number of essential roles in the human body; they maintain the health and flexiblity of cell membranes, ensure the maintenance of oxidant-antioxidant balance with antiinflammatory action etc. [6]

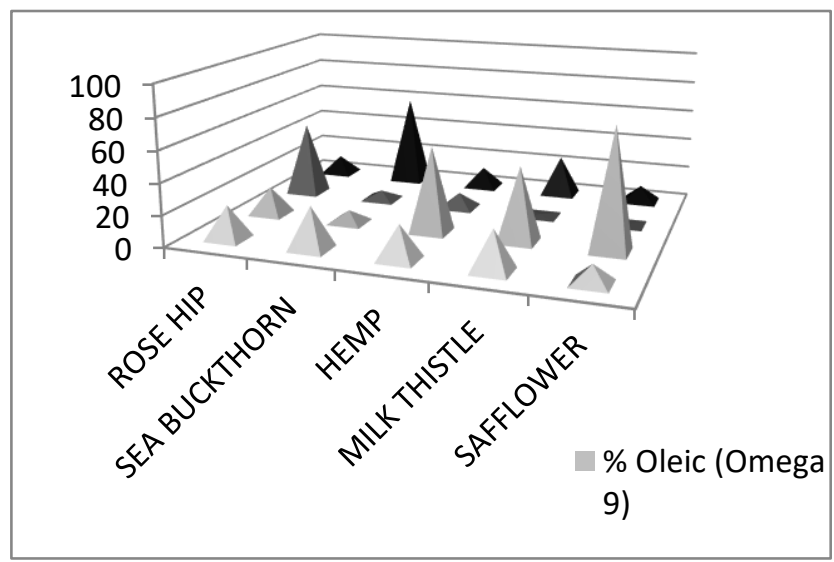

Fig. 2. Unsaturated fatty acid composition of used oils

Rose hip oil, predominantly used by the authors, has an important antioxidant action, by combating free radicals, eliberating skin from harmful substances and impurities; a moisturizing effect by the quick penetration of dry skin and $\mathrm{pH}$ equilibration capacity; it is a strong cicatrizant and regenerat for skin; its anti-aging properties come from the high content of retinol determining the revitalization of cells, blurring wrinkles and restoring normal texture of skin. [7]

Further, in Table 1, the vegetable raw materials selected for the new range of cosmetics are presented, as well as their compositional phytochemical compounds of interest and their properties. By UV-VIS, IR, HPLC, thin layer chromatography, etc. 
analyzes, several dosing and identification for some of the following compounds from the used plant material were performed: flavones, polyphenols, tannins, saponins triterpene, fatty acids, vitamin E, etc.; also, related technical specifications were drafted.

Table 1. Vegetal material with cosmetic potential

\begin{tabular}{|c|c|c|}
\hline Vegetal material & $\begin{array}{c}\text { Active chemical } \\
\text { compounds of interest }\end{array}$ & Properties \\
\hline $\begin{array}{l}\text { Passiflora Flower } \\
\text { Passiflora Incarnata (extract) }\end{array}$ & $\begin{array}{l}\text { Flavonoids, polyphenols, maltol, } \\
\text { ethilmaltol, cumarins, sterols, } \\
\text { polyuronides }\end{array}$ & $\begin{array}{l}\text { moisturizes, soothes, softens and } \\
\text { improves skin barrier function; } \\
\text { reduces water loss; fights toxins from } \\
\text { the environment; indicated in } \\
\text { restoring sensitive skin, dehydrated } \\
\text { and with couperose trendency }\end{array}$ \\
\hline $\begin{array}{l}\text { Althaea officinalis } \\
\text { Marshmallow (extract) }\end{array}$ & $\begin{array}{l}\text { Flavonoids, phenolic acids, } \\
\text { caffeic acid, p-coumaric acid, } \\
\text { aminoacids, polysaccharides }\end{array}$ & emollient, antiwrinkle, nourishing \\
\hline $\begin{array}{l}\text { Ribes nigrum } \\
\text { Black current (extract) }\end{array}$ & $\begin{array}{l}\text { Triterpenic derivatives, phenolic } \\
\text { acids, terpenes, quinones, } \\
\text { hydroquinones }\end{array}$ & $\begin{array}{l}\text { Regenerative, cicatrizating, } \\
\text { antimicrobial, anti-inflammatory }\end{array}$ \\
\hline $\begin{array}{l}\text { Glycyrrhiza glabra } \\
\text { Licorice (extract) }\end{array}$ & $\begin{array}{l}\text { Triterpenic saponines, } \\
\text { flavonoids, tannins, cumarines, } \\
\text { ferulic acid, benzoic acid, free } \\
\text { aminoacids, lipids, eteric oil, } \\
\text { grup B vitamins }\end{array}$ & $\begin{array}{l}\text { Antioxidant, balsamic, emollient, } \\
\text { cicatrizating, anti-inflammatory }\end{array}$ \\
\hline $\begin{array}{l}\text { Cannabis sativa } \\
\text { Hamp seed (oil) }\end{array}$ & $\begin{array}{l}\text { Ess. fatty acids: palmitic, oleic, } \\
\text { linoleic, linolenic; flavanols, } \\
\text { Polyphenol; vitamin E; beta } \\
\text { sitosterol }\end{array}$ & $\begin{array}{l}\text { moisturizing, } \\
\text { regenerative, } \\
\text { anti-allergic }\end{array}$ \\
\hline $\begin{array}{l}\text { Rosa canina } \\
\text { Roseship (oil) }\end{array}$ & $\begin{array}{l}\text { Ess. fatty acids: palmitic, oleic, } \\
\text { linoleic, linolenic, trans-retinoic } \\
\text { acid }\end{array}$ & $\begin{array}{l}\text { Antioxidant, cels regenerating, } \\
\text { protective }\end{array}$ \\
\hline $\begin{array}{l}\text { Hippophae rhamnoides } \\
\text { Sea bckthorn (oil) }\end{array}$ & $\begin{array}{l}\text { lipids (glicerides of palmitic, } \\
\text { oleic, linoleic, linolenic acids); } \\
\text { carotenoides; palmito-oleic acid; } \\
\text { vitamins: } \mathrm{A}, \mathrm{D}, \mathrm{E} \text {; triterpenes; } \\
\text { minerals: } \mathrm{Fe}, \mathrm{Se}, \mathrm{Zn}, \mathrm{K}, \mathrm{Na}, \mathrm{Ca} \text {, } \\
\mathrm{Mg}, \mathrm{Cu} \text {; sterols; sitosterol; }\end{array}$ & $\begin{array}{l}\text { Regenerating, cicatrizating, tonic, } \\
\text { anti-inflammatory, vitaminizing }\end{array}$ \\
\hline $\begin{array}{l}\text { Silybum marianum } \\
\text { Milk thistle (oil) }\end{array}$ & $\begin{array}{l}\text { polyunsaturated fatty acids; } \\
\text { sitosterols }\end{array}$ & $\begin{array}{l}\text { Anti-inflammatory, emollient, solar } \\
\text { and radiation protective }\end{array}$ \\
\hline $\begin{array}{l}\text { Carthamus tinctorius } L . \\
\text { Safflower (oil) }\end{array}$ & $\begin{array}{l}\text { Mono and polyunsaturated fatty } \\
\text { acids; vitamin E }\end{array}$ & $\begin{array}{l}\text { Emollient, lubricating, regenerative, } \\
\text { soothe }\end{array}$ \\
\hline
\end{tabular}

This unique 'cocktail' of: polyunsaturated fatty acids, polysaccharides, enzymes, vitamins, polyphenols, flavonoids, enzymes, substances with restorative and refreshing effect, associated in a nearly perfect balance by mother nature and developed by plant species was used by the authors for the obtaining of five cosmetics with roles of: skin care through nutrition, hydration and cellular regeneration by stimulating the self-regenerative and skin protection capacities, strengthening the 'natural barrier' and the natural defense mechanisms, preventing and delaying aging and not lastly, mitigation of fine wrinkles and expression lines.

Thereby, five formulations of cosmetics were developed, respectively: Cleansing and toning milk for face; Cleansing oil for eye area; Moisturizer and protective day cream; 
Nourishing and relaxing body cream; Anti-stress shampoo. Products are detailed in Table 2.

Table 2. Care cosmetic products for protection against environmental pollutants

\begin{tabular}{|c|c|c|c|}
\hline PRODUCT & $\begin{array}{c}\text { ACTIVE } \\
\text { INGREDIENTS }\end{array}$ & ACTION / EFFECT & RECOMMENDATIONS \\
\hline $\begin{array}{l}\text { Cleansing } \\
\text { and toning } \\
\text { milk for face }\end{array}$ & $\begin{array}{l}\text { Oils of: thistle, } \\
\text { safflower } \\
\text { Extracts of: Passion } \\
\text { Flower, licorice; } \\
\text { Passion Flower } \\
\text { perfume; lavender } \\
\text { ess. oil }\end{array}$ & $\begin{array}{l}\text { Action: gentle and effective } \\
\text { clean of makeup and skin } \\
\text { impurities; invigorates and } \\
\text { refreshes the skin; ensures the } \\
\text { maintenance of hydro-lipid } \\
\text { protective film of the skin; } \\
\text { maintains the normal } \\
\text { physiological pH value; } \\
\text { Effect: leaves skin clean with a } \\
\text { feeling of freshness }\end{array}$ & $\begin{array}{l}\text { Apply with fingertips by } \\
\text { gently massaging on face } \\
\text { and neck. Remove with } \\
\text { floppy disks or sterile } \\
\text { cleansing wipes. } \\
\text { Recommended in the } \\
\text { morning before applying } \\
\text { creams and makeup or in } \\
\text { the evening }\end{array}$ \\
\hline $\begin{array}{l}\text { Cleansing oil } \\
\text { for eye area }\end{array}$ & $\begin{array}{l}\text { Oils of: safflower, } \\
\text { rosehip, thistle, hemp; } \\
\text { Passion Flower } \\
\text { perfume }\end{array}$ & $\begin{array}{l}\text { Action: allows gentle and } \\
\text { quick removal of makeup and } \\
\text { accumulated impurities } \\
\text { Effect: soothing effect on the } \\
\text { skin, reducing inflammation }\end{array}$ & $\begin{array}{c}\text { Apply daily, in the } \\
\text { evening, by gentle } \\
\text { massage of finger tips. }\end{array}$ \\
\hline $\begin{array}{l}\text { Moisturizer } \\
\text { and } \\
\text { protective } \\
\text { day cream }\end{array}$ & $\begin{array}{c}\text { Oils of: rose hip, } \\
\text { syllibium marianum, } \\
\text { hemp, sea buckthorn, } \\
\text { safflower; Extracts of: } \\
\text { Passion Flower, } \\
\text { licorice, black current; } \\
\text { Passion Flower } \\
\text { parfume, levender } \\
\text { ess. oil }\end{array}$ & $\begin{array}{l}\text { Action: deeply moisturizes; } \\
\text { blocks free radicals } \\
\text { responsible for premature skin } \\
\text { aging; protects the skin } \\
\text { against the destructive action } \\
\text { of pollutants; increases the } \\
\text { capacity of natural skin } \\
\text { protection; provides protection } \\
\text { against harmful effects of free } \\
\text { radicals and UV radiation; } \\
\text { prevents premature skin } \\
\text { aging; } \\
\text { Effect: skin becomes brighter, } \\
\text { more supple and smooth; it is } \\
\text { an excellent base for makeup. }\end{array}$ & $\begin{array}{l}\text { Apply by gentle massage } \\
\text { of fingertips until } \\
\text { complete absorption into } \\
\text { the skin. Recommended } \\
\text { in the morning or during } \\
\text { the day, after cleansing } \\
\text { and toning with cleansing } \\
\text { milk. }\end{array}$ \\
\hline $\begin{array}{l}\text { Nourishing } \\
\text { and relaxing } \\
\text { body cream }\end{array}$ & $\begin{array}{l}\text { Oils of: rose hip, milk } \\
\text { tristle, hemp, } \\
\text { safflower; Extracts of: } \\
\text { Passion Flower, } \\
\text { marshmallow; } \\
\text { Passion Flower } \\
\text { parfume, levender } \\
\text { ess. oil }\end{array}$ & $\begin{array}{l}\text { Action: supplies all the } \\
\text { nutrients needed by the skin; } \\
\text { favors the regeneration } \\
\text { process; maintains and } \\
\text { improves skin elasticity and } \\
\text { firmness; reduces the } \\
\text { appearance of wrinkles and of } \\
\text { fine lines; provides an anti- } \\
\text { inflammatory and soothing } \\
\text { touch; } \\
\text { Effect: skin becomes smooth, } \\
\text { firm and supple }\end{array}$ & $\begin{array}{l}\text { Apply by gentle massage } \\
\text { to facilitate absorption } \\
\text { into the skin. } \\
\text { Recommended every 2-3 } \\
\text { days, on the clean } \\
\text { surface of the body }\end{array}$ \\
\hline $\begin{array}{l}\text { Anti-stress } \\
\text { shampoo }\end{array}$ & $\begin{array}{l}\text { Extracts of: Passion } \\
\text { Flower, black current, } \\
\text { ess. oil of levender } \\
\text { and sage; } \\
\text { Passion Flower } \\
\text { parfume; } \\
\text { ecological surfactant } \\
\text { agents; }\end{array}$ & $\begin{array}{c}\text { Action: removes accumulated } \\
\text { impurities, restores the hydro- } \\
\text { lipid barrier of hair, invigorates } \\
\text { and strengthens the hair, } \\
\text { activating blood circulation of } \\
\text { scalp, preventing dehydration } \\
\text { of hair and scalp; } \\
\text { Effect: the hair remains clean, } \\
\text { smooth, silky and easy to } \\
\text { comb }\end{array}$ & $\begin{array}{c}\text { Apply to damp hair, } \\
\text { distribute evenly by light } \\
\text { massaging to form a fluffy } \\
\text { and perfumed foam; rinse } \\
\text { thoroughly with plenty of } \\
\text { water; } \\
\text { Recommended every 6-7 } \\
\text { days during the winter } \\
\text { and every } 2-3 \text { days during } \\
\text { the summer. } \\
\end{array}$ \\
\hline
\end{tabular}


The obtained fitocosmetice products were analyzed both in terms of physico-chemical characteristics, and of effectiveness, stability, tolerance and safety on human skin [8].

The products were realized with modern manufacturing technologies, which protect the phytoactive components, supporting an enhanced skin care, favoring the maintainance of beauty and health appearance and satisfying the ecological concept through the used plant material.

\section{Conclusions}

The authors have experimented and developed new formulas and technologies for five new hygiene and biocosmetic products, presented in this paper and with very good testing results;

Physicochemical and microbiological analyzes were performed by appropriate methods to determine the main phytoactive components of cosmetic interest, for the presented plants and plant materials;

Technical specifications have been constituted for both elaborated products and used extracts;

The products were investigated in terms of efficacy upon skin and hair. Assesment results reveal that the developed biocosmetics do not produce or have any adverse effects on the skin, but only beneficial;

The association of vegetable extracts and oils of the plants specified in the work conducted, in the first stage, at the obtaining of 5 products with customed, outstanding cosmetic effects, that ensure the health and beauty of skin and hair.

\section{References}

1. Milles S.,Bone K., (2000), Principles and Practice of Phytotherapy: Modern Herbal Medicine, ed. Ch Livingstone, 2nd Edition

2. Weiss, R. F., Fintelman U., (2000), Herbal Medicine, ed. Thieme, Stuttgart New York

3. Bartram T. H., (2002): Bartram's Encyclopedia of Herbal Medicine, ed. Robinson, London.

4. Kim J. H., Lee B. C., Pyo B. H., (2005), The isolation and antioxidative effects of vitexin from Acer palmatum, Archives of Pharmacal Research

5. Lee ER, Kang GH, Cho SG., (2007), Effect of flavonoids on human health: old subjects but new challenges., Recent Pat Biotechnol

6. Zielinska A., Nowak I.,(2014), Fatty acids in vegetable oils and their importance in cosmetic industry,.Chemik, Poznan, Poland, p.103-110

7. Valerón-Almazán P., Gómez-Duaso A. J., Santana -Molina N., García-Bello M. A., Carretero G., (2015), Evolution of Post-Surgical Scars Treated with Pure Rosehip Seed Oil Journal of Cosmetics, Dermatological Sciences and Applications, p.161-167 8. Dumitru, B., Croitoru, C., Olariu, L., (2007), Functional status of the skin; testing methods in dermatocosmetics. RSCC Magazine, p.24-31. 